\title{
THE FATHER SHOWS THE SON EVERYTHING. THE IMAGERY OF EDUCATION IN JOHN 5:19-23
}

\author{
J.G. Van der Watt \\ (University of Pretoria)
}

\begin{abstract}
The remarks in John 5:19-23 should be understood in the context of education practices in ancient times. The dynamics of the metaphorical language used in these verses are explored and related to the appropriate socio-cultural framework. The Father educates the Son and prepares him for his mission. He teaches him to give life and to exercise eschatological judgment. This legitimizes the position of Jesus as the one who works like his Father does.
\end{abstract}

\section{Introduction}

In the middle of the previous century Dodd identified the "perfectly realistic description of a son apprenticed to his father's trade" in 5:19-20a as a parable, which is based on typical ancient educational practices and is then allegorically interpreted and applied in the following passage to the Father and the Son (5:20b-30). ${ }^{1}$ Subsequently scholars expressed reservations as to whether this really was a parable. ${ }^{2}$ After expressing their reservations they usually refrained from posing any further background to their stated position by simply paraphrasing what the text says and relating this to the wider theology of the Gospel. Although the term parable was not accepted as an apt description of this textual phenomenon, further research has pointed out that these remarks in 5:19-23 form part of the larger metaphorical network of family metaphors in the Gospel and should therefore be read as figurative language. ${ }^{3}$

Language is a social phenomenon. Texts express social conventions and are also embedded in social contexts. The form of the text should therefore always be interactively related to it socio-cultural ecology.

As has already been mentioned, Dodd pointed to the two aspects of the imagery, namely the description of a situation in real life that is then allegorically interpreted and applied to the Father and the Son. Theoretically the semantic interaction between socio-cultural ecology and the form of the text in the process of generating meaning is of great significance. "Real life imagery" means that the imagery is taken from the situation as it is determined by its own social, historical, and cultural 
restrictions. The situation is "bound" in time and space. To understand the semantic dynamics of the imagery it is therefore important to understand the socio-cultural ecology of the imagery. Many of the socio-cultural aspects are implicit, although some are made explicit.

Having said this, the preferred point of departure should be clear. Due to our distance from the origin of the text (2000 years) it is necessary to reconstruct the socio-cultural ecology within which the text is to be read. In doing so, however, we are confronted with several problems. Material to do so is not easily available, the material that we do have comes from different social strata and locations, and we are not sure what exactly the author of the Gospel had in mind when he wrote the Gospel. The result of this is that we should first carefully read the text "as it is". This attentive reading has the purpose of foregrounding the issues and aspects that the author wants the reader to note. Obviously, the view the author has will become apparent in analyzing the text. After describing the profile of the text thoroughly one will arrive at what can be characterized as the "Johannine view". Now we can see whether there is similar or at least related socio-cultural information that can enrich our understanding of this particular imagery. To put it differently: the form of the texts will be embedded into the appropriate socio-cultural ecology. This link between "form" and "social ecology" is important, since the manner in which imagery functions is by using a culturally bound social phenomenon to express a particular message. Imagery is a social-linguistic phenomenon. This process will be illustrated the section that follows.

\section{The metaphorical dynamics of this text $(5: 19-23)$ \\ 2.1 The logical flow of the text $(5: 19-23)$}

The argument in 5:19-23 is logically developed in stages.

a) In the first stage $(5: 19)^{4}$ what the Son does is linked to what the Father does, since the son copies his father after watching him carefully. Rhetorically the author starts his argument with - for us as present day readers - a questionable remark that the Son cannot do anything on his own

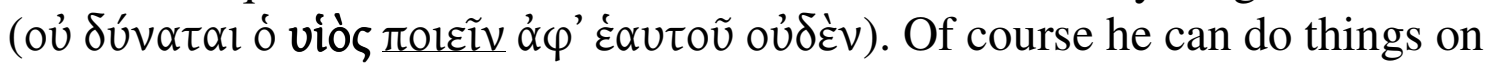
his own, if he wants to, yet in this case it does not seem to be an option for him. The Son has no wish to act on his own initiative ( $\left.\alpha^{\prime} \varphi^{\prime} \dot{\varepsilon} \alpha u \tau o \tilde{v}\right)$. Rather, the determinative source and pattern of his actions are the deeds of his

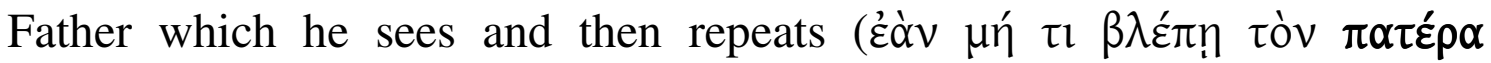
$\pi 010 \tilde{v} \tau \alpha)$. 
b) The second stage $(20)^{5}$ contains two brief but related remarks, although the relation is not grammatically encoded. The Father loves the Son and (кaí) he shows him everything he does. ${ }^{6}$ It may be assumed that because the Father loves the Son, he shows him everything. There will even be an increase in intensity when the Father shows him bigger things that will lead to the amazement of "them". 7

c) In the third stage (5:21-22) three important aspects are touched upon.

i) What the Son does: Like the Father the Son will also give life ( will only do what he sees the Father doing. The Father gives life, thus the Son will also give life (10:17-18; 11:25-26).

ii) What the Father does: The Father entrusted judgment to his Son.

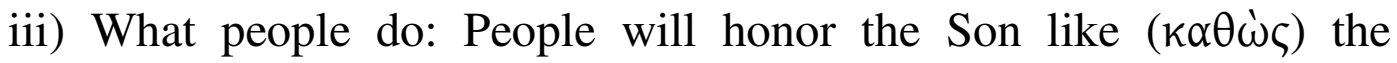
Father. Their honor will be intricately linked.

In this stage the question is thus answered: what did Jesus see his Father doing? The "work" of the Father is to raise people from death, to give them life, and also to judge them (5:21-22 and 5:26-27). ${ }^{8}$ Jesus also gives life as his Father does (see the parallel in 5:21), because the Father has imparted life to him to have within himself $(5: 26)$. Jesus can give life to whomever he wishes $(5: 21)$, which emphasizes the reality of Jesus' sharing of the power ${ }^{9}$ and knowledge of the Father (see also 3:34-35). In the same way, Jesus judges in absolute accordance with the judgment of the Father (5:30), so much so, that it is stated that the Father no longer passes judgment (5:22). Although, when Jesus defends himself against the Pharisees in 8:16 he remarks, "my judgment is true; for I am not alone, but it is I and he who sent me". ${ }^{10}$ The educational process does not only exist in mediating knowledge, but also the power, the authority and the ability to do these things are mediated. ${ }^{11}$ Jn. 3:35 affirms that the Father gives everything into the hand of Jesus; that is why Jesus can do what he does (see also 17:2). When Jesus gives life and judges, people will honour him like they honour the Father (5:23-24). This action will illustrate that Jesus' remark is true, that his Father is still working and that he (Jesus) is also working (5:17). The work of the Father, namely to give life or to judge, is continued by Jesus. Thus, one can conclude that he was well educated by his Father.

\subsection{The figurative nature of the text}

Dodd remarked that 5:19-20a is a real life event, based on ancient educational practices and can therefore be reckoned as parable. ${ }^{12}$ What he 
missed was that the literal and figurative levels of the text are already metaphorically integrated by way of analogy. This means that the "father" already refers to God and the "son" to Jesus. ${ }^{13}$ There are several textual indications for this remark. Contextually the Father is directly linked to God and Jesus implicitly linked to the Son in the preceding verses (5:1718). This is formative for the analogy to follow in 5:19-23. In 5:20 the hearers (í $\mu \varepsilon \tilde{\imath} \varsigma)$ are referred to as partaking in these events. This implies that the divine events that will amaze them should be analogously understood in terms of a father showing his son everything - only in this case the Father is God and the Son is Jesus.

The framework within which the figurative language unfolds seems to be filial. The father stands in a relationship to his son and acts in relation to him, and vice versa. What happens, happens between a father and a son. Indeed, this is the language of a family.

\subsection{The metaphorical dynamics of this imagery}

The metaphorical dynamics may be described as follows: This is a composite metaphor, consisting of several different metaphors that are combined to form a metaphorical network.

a) There are metaphors of substitution. Father substitutes God and Son substitutes Jesus. When "father" is used, it may be substituted with "God" on the level of the metaphor. The teacher of Jesus is not an ordinary teacher, but his Father, God. ${ }^{14}$

b) There are metaphors of interaction. Metaphorical interaction mainly resides in the verbs. Analogy plays an important role. ${ }^{15}$ Exactly at the point of similarity the difference lies. Both an ordinary son and Jesus "sees" - but the way an ordinary human sees his father and the way Jesus sees his father are significantly different in nature. Both an ordinary father and God show their children what they do, but the way in which they do that differs. What God does with Jesus is analogous with what an ordinary father does with his son.

The metaphors of substitution and interaction are combined to form a comprehensive imagery. It should now be determined what type of imagery this is. 


\section{The socio-cultural ecology underlying this image}

The question now is: which socio-cultural situation will come closest to forming the most plausible framework for understanding the remarks in 5:19-23. In other words, which situation should be visualized where a father loves his son so much that he shows him everything so that his son sees and can do exactly the same things? If the son does not see what his father does he is not really able to act or at least will not want to act.

It seems as if there are two possibilities: it could either be an educational situation or it could be somebody preparing and agent for a mission. The latter possibility is considered because the mission is mentioned in 5:23. However, the mission does not seem to function as a primary focus in this section. It is not stated that the Father prepares the Son for a mission. The emphasis is rather on the question why Jesus can do what his Father does (5:17). Rather, the relationship between the Father and the Son receives attention.

Hence the educational framework seems to be the most plausible sociocultural framework within which to understand this image. This becomes apparent when comparing the socio-cultural information with the different dimensions of the imagery. It is also confirmed in other places in the Gospel. In 8:28 Jesus indeed uses the term "taught" - $\dot{\epsilon} \delta i \delta a \xi \in \nu$ - to indicate this educational interaction between the Father and the Son which has a direct impact on his actions. That a child does what his father does, is explicitly stated $(8: 38,41)$. This implies an educational framework.

One should therefore ask: What were the social dynamics of education in ancient times and how can they be related to our text? In a study of this nature it is not possible to touch on every aspect of the educational context. Only those aspects that will help to highlight the imagery will receive attention here.

In spite of the variety and multiplicity ${ }^{16}$ of education in ancient times John most probably had Jewish education in mind, including, for instance, moral $^{17}$ or religious education, and vocational training (1 Sam 16:11; 2 Kings 4:18). Jewish education on all levels was the responsibility of the parents (Proverbs $1: 8 ; 6: 20 ; 23: 22)$ and in general it was the father who was regarded as his son's teacher. ${ }^{18}$ Initially it was the same in the Greco-Roman world, but with urbanization and the introduction of more formal schools a more formal education than just that offered by a parent became important (Plutarch The 
life of Marcus Cato XX 4-7). However, the latter does not seem to be what John has in mind here.

Let us investigate some of the similarities between our imagery and the socio-cultural ecology:

The Father loves his Son ${ }^{19}$ and shows the Son everything as the Son observes him: The Father is the dominant actor: ${ }^{20}$ giving, showing, sending, entrusting, and loving his Son. ${ }^{21}$ This corresponds with the ancient situation where the father was the undisputed head of the family. ${ }^{22}$ Therefore the Son obeys his Father and does what the Father does (see 7:15-16). ${ }^{23}$ What the Father does, the Son does also. ${ }^{24}$ This is indeed in line with ancient educational practices. ${ }^{25}$

The way a son - between approximately five and seven years old - was prepared for his occupation would normally be to watch and listen to his father and in this way learn that profession ${ }^{26}$ (1 Sam 16:11; 2 Kings 4:18. It was possible to send your son as apprentice to work with another person who is a specialist in another trade). The son memorized what he saw although "hearing" is not mentioned here, it is obviously implied. The Gospel does not make a strong distinction between seeing and hearing as a means of acquiring knowledge. Often, when one is mentioned in a context the other is simply implied. In the ancient Near East the general method of teaching also involved oral repetition aimed at memorizing the text or message being taught. ${ }^{27}$ This could form the background to Jesus only saying what he heard from the Father $(8: 26,40)$. Jesus remarks that his

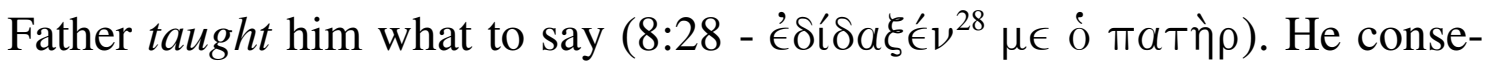
quently only speaks what he has heard and seen from the Father (the remarks in 8:26,38 and 40 are isotopes of 8:28, linking hearing to being taught). Jesus memorized and consequently did exactly what he was taught by his father, as would be expected of every obedient child in his context.

Apart from this vocational training, the fathers also had the responsibility to teach their children responsible behaviour ${ }^{29}$ according to the traditions and customs of their families (= mos maiorum). ${ }^{30}$ "The parental role was vital to the development of a child's character". ${ }^{31}$ Philo (De Spec Leg II.236) remarked that no father would give his child instruction that was foreign to virtue. $^{32}$ In a patriarchal society the fathers, as the representatives of the family group, were the carriers of the tradition of the family. This tradition actually represented the "character" of that particular family. ${ }^{33}$ These traditions were highly regarded as something to protect and desire (Josephus 
Ant. 1.3.1 §72; 1 Macc 1:54-58; 2:15-28; 4:36-43). The father passed this tradition on to his children, as persons who are embedded in that family as a social unit. The child was therefore under social (and usually religious) pressure to obey the father in order to protect and extend the character of the family. ${ }^{34}$ A telling description of this practice is given by Josephus (Ant. 1.2.3, 68-69): "He [=Seth] after being brought up and attaining to years of discretion, cultivated virtue, excelled in it himself, and left descendants who imitated his ways. These being all of virtuous character, inhabited the same country". Consequently obedience was regarded as one of the cornerstones of ancient families (cf. for instance, Prov 1:8; 6:20; 23:22-25) and that is why a good man was one who acted according to the will of the father ${ }^{35}$ and thus reflected in his actions the character or traditions of his family. This idea is also reflected in the argument of the opponents that they are the seed of Abraham (8:33) ${ }^{36}$ implying that this is where their roots lie and this is their tradition. ${ }^{37}$ Jesus remarks that they no longer act according to the tradition of their father Abraham, since they do what would not have done (8:40). The important act of respecting and obeying their tradition as people embedded in the family of Abraham was thus lacking in their behaviour. This state of affairs is enough to disqualify them from being part of that tradition any longer. For this argument to be convincing, the social reality of patriarchal transmittance of tradition and the obligation to keep that tradition by the children should be accepted as valid.

Ancient personalities were also judged according to their education (see also 7:15) and this might be the background to the remark that people will honor the Son like they would honour his Father. ${ }^{38}$ In 7:15 the Jewish

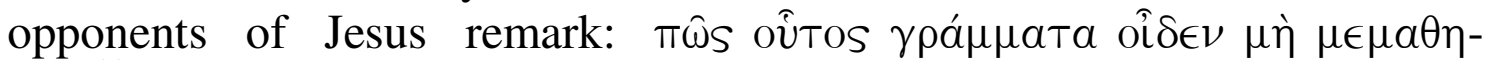
$\kappa \omega ́ s ;{ }^{39}$ Since the social status and honour of a person depended, among other things, on his education, ${ }^{40}$ this questions the ability as well as the status of Jesus. Learners bore the stamps of their mentors and teachers: "young men were only as good as their teachers and those who formed them in the social values enshrined in their past culture". The remark by the Jewish opponents is thus ironic. They do not know who taught Jesus, although Jesus' knowledge makes it apparent that he must have had an important teacher, whom they were supposed to know. Jesus identifies his teacher as the one who has sent him, namely God (7:16ff.). The honour he therefore seeks is not his own, but that of his teacher - the Father. Thus when they realize that the Son does what is considered prerogative of God the Father that is, to give life and judge, they will honor him. 


\section{Conclusion}

The dynamics of this educational process as it is reflected in the description of Jesus' relation with his Father may be found in ancient family conventions. ${ }^{42}$ The Father is the dominant actor: ${ }^{43}$ giving, showing, sending, entrusting, and loving his Son. ${ }^{44}$ This corresponds with the ancient situation where the father was the undisputed head of the family. ${ }^{45} \mathrm{He}$ was responsible for protecting the tradition of the family, which automatically implied proper education and discipline. Sons were obliged to obey the Father. As an ideal son, the Son obeys his Father and does what the Father does (see 7:15-16) ${ }^{46}$ What the Father does, the Son also does. ${ }^{47}$ "The activity of Jesus is not merely a reflection of one aspect of God's activity but rather a complete reflection of God, since the Father shows the Son all that he does". ${ }^{48}$ This is indeed in line with ancient educational practices. ${ }^{49}$ By identifying the relevant socio-cultural ecology of John 5:17ff the dynamics and communicative power of these sayings become apparent.

\section{BIBLIOGRAPHY}

Barrett, C.K. 1978

The Gospel according to St John. $2^{\text {nd }}$ ed., London.

Brown, R.E. 1971

The Gospel according to John. (i-xii) Vol. 1. New York.

Bühner, J.-A 1977

Der Gesandte und sein Weg im 4. Evangelium. Tübingen.

Burge, G.M. 2000

The Gospel of John. Grand Rapids.

Carson, D.A. 1991

The Gospel according to John. Leicester.

Christ, K. 1984

The Romans: An Introduction to their History and Civilisation. London.

Dixon, S. 1991

The Roman Family London.

Dodd, C.H. 1963

Historical tradition in the Fourth Gospel. Cambridge. Johnson, T. 1995

The social world of James: literary analysis and historical reconstruction in The social world of the first Christians: Essays in honor of W.A. Meeks. White, L.M. and Yarbrough, O.L. (eds.) Minneapolis. 
Keil, C.F. 1888

Manual of Biblical Archaeology. Edinburgh.

Köstenberger, A.J. 2004

John, Grand Rapids.

Lemaire, A. 1992

Education in Anchor Bible Dictionary. New York.

Neyrey, J.H. 1996

The trials (forensic) and tribulations (honor challenges) of Jesus: John

7 in Social Science Perspective, BTB 26(3).

Roberts, J.W. 1984

City of Socrates: An Introduction to Classical Athens. London.

Shelton, J.-A. 1988

As the Romans did. A source book in Roman social history. Oxford.

Schnackenburg, R. 1977

Das Johannesevangelium, III. Teil, Kommentar zu Kap. 13-21

Freiburg.

Van der Watt, J.G. 2000

Family of the King. Dynamics of metaphor in the Gospel according to John. Leiden.

Van Tilborg, S. 1993

Imaginative love in John. Leiden.

Whitacre, R.A. 1999

John. Leicester.

Zimmermann, R. 2004

Christologie der Bilder im Johannesevangelium. Tübingen.

\section{NOTES}

$1 \quad$ Dodd (1963:386); Burge (2000:177).

2 Obviously the definition of what a parable is would determine whether one would call this a parable. See Whitacre (1999:126); Köstenberger (2004:186).

3 Van der Watt (2000).

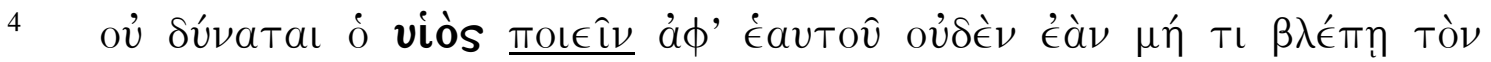

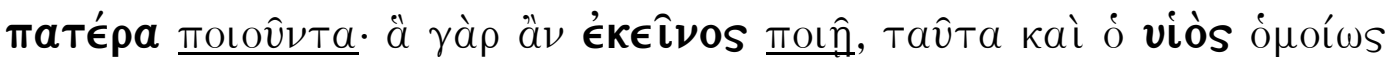
$\underline{\pi O L} \in \hat{\imath}$.

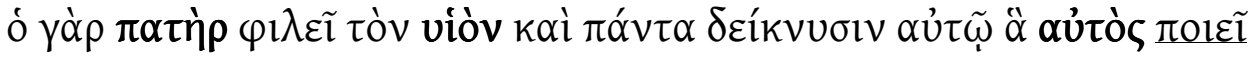

In 5:19 an "open" conditional construction is used, which does not necessary bind the condition only to the present, but whenever it occurs. It is therefore a relatively "open" condition which makes contact with the 
Father possible, in the present, but it does not exclude contact in the past. This is consistent with the permanent relation, which exists between the Father and the Son, which excludes any limitation of contact. The use of the present as well as future forms of $\delta \in \mathbf{i} \kappa \nu \cup \mu \mathrm{u}$ in 5:20, suggests a continuing process. It happened; it happens, and it will still happen. In 5:21-23 the

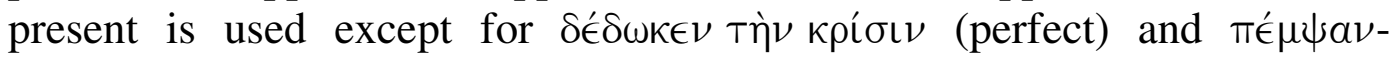
Ta (aorist). The handing over of judgment is therefore an act which took place in the past (see also 5:27 - aorist), as well as the act of sending the Son (see also 5:30). The other actions are still continuing. The whole process of learning and receiving from the Father is a continuing process, which are embedded in their familial relationship. This conclusion seems to support the view that one can look for indications in the Gospel itself where the Son hears and sees the Father, (and this is not strange in the Gospel, since the Father is with Jesus; their relationship continues - 10:38; 14:10), but not exclusively. Jesus was with the Father from the beginning $(1: 1,18$; 7:29).

7 This latter part (20b) is seen as an addition and not part of 20a that should rather be read with verse 19. This is not, however, critical for our purpose.

8 Life and judgment are two sides of the same coin in this Gospel. Brown (1971:219) calls judgment "the prerogative of Yahweh". See Carson (1991:252).

9 God has indeed given Jesus the power and ability to do what only God can do, such as giving life or to judge (5:20-22, 27). See Schnackenburg (1977:134-135). This theme reoccurs several times in the Gospel. In 3:35-36 it is stated that the Father loves Jesus and places everything in his hands

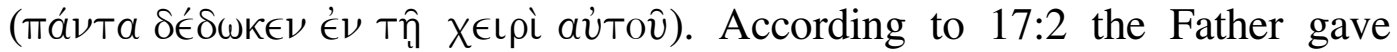

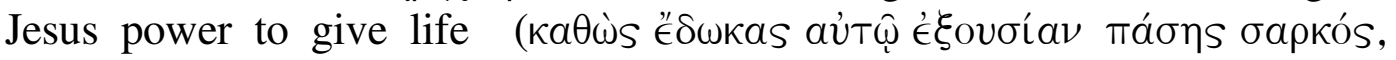

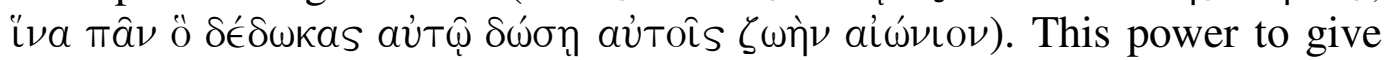
life even extends to having power over his own death and life (10:17-18). These statements form a close parallel to what is said in 5:20-21 and should be read in relation to one another. Although the references occur in contexts where familial language is found apart from 5:20-21, the educational nature of these expressions is established in 5:20-21.

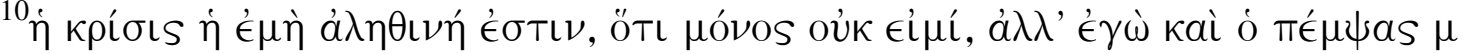
$\in$ тати́p.

11 Bühner (1977:245) maintains: “Gott hat die ihm zustehende Gerichtsmacht an seinen bevollmächtigten... delegiert".

12 Dodd (1963:386)

13 See van der Watt (2000), Zimmermann (2004) for the theoretical background to this remark.

14 Note that the term $\theta \in$ ÓS is not exclusively used of the Father. It is also used of Jesus $(1: 1,18 ; 20: 28)$ and in a different context of everybody who 
receives the word of God (10:34). In this context (v. 18) the term God is, however, used to refer to the Father.

See Van der Watt (2000) for a description of how analogy works.

16 Education in ancient times differed widely from area to area, varied on different levels of society, and also evolved over time. A general description of education in ancient times is not possible. John does however give us some indications of what he has in mind when using the imagery of education. Most probably John had Jewish education in mind, which included different types of education, for instance, moral or religious education, vocational training, and obviously more specialized training for the elected few. See Lemaire 1996:ad loc.).

17 See for instance Tosefta Qiddushin I, 11b where it is stated that the father has the following responsibilities towards his son: he must circumcise his son, must redeem him, he must teach his son the Torah, he must teach him a trade and must see that he gets a wife. Obviously, there were different forms of education. See Shelton (1988:104). A father could teach his son the basics of life, which usually included a trade and in the case of the Jews the Torah.

18 Shelton (1988:104) remarks that this is also true of the Roman world.

19 This serves as ground for the education process. See 3:35 and Carson (1991:251).

Van Tilborg (1993:30) also points out that the Father is presented as an ideal Father. See Sir. 30:1-5.

Johnson (1995:196) mentions: "The transmission of wisdom from father to son is, of course, the standard mise-en-scène of parenesis". See Roberts (1984:63).

"From Homeric to historical times Greek society remained founded on the oikos or household, with the father's power therein almost unfettered. It was the business of the father to pass on the oikos to his son at least as strong as he had inherited it" (Roberts 1984:157). This implies a strong educational tradition.

It must be noted that the fact that a child acts as his father does was not only due to the education of that particular child by the father. It was also due to that person's bloodline. Pliny the Younger (Letters 8.10) emphasizes that his children will be good politicians because they will have a long line of famous political ancestors.

24 Education did not only have economical value, but also served as way in which family tradition was protected and handed on from generation to generation. In 1 Macc. 2:15-28 (see also 1:54-58 and 4:36-43) it is described how Mattathias and his sons are asked to obey the king. Mattathias answered that he would rather stick to his own traditions and stay loyal to the covenant of his ancestors. From that passage the corporate 
effect of his decision is clear. Plutarch (The Life of Marcus Cato 20.4-7) tells with great care how Cato gave his son "the opportunity at home to become familiar with his society's ancient customs and traditions" (Shelton 1988:105).

Obviously it is not implied that all throughout the ancient world people educated their children like this and that this was the only possible means of education. What is said here is that similar patterns of education are wellknown in the ancient world. In any case, John himself gives the reader an indication of what he thinks takes place during the educational process of Jesus by the Father.

This was an important way to transmit knowledge. Children were expected to carefully observe their parents and then copy them. See Shelton (1988:118). See also Dt. 21:18.

27 Lemaire (1996:ad loc.)

28 John only uses $\delta\llcorner\delta a ́ \sigma \kappa \omega$ and derivatives and not $\pi \alpha \iota \delta \in \dot{v} \omega$ and derivates. In the light of 5:19ff. this teaching by the Father, which is later described with the verb $\delta\llcorner\delta a ́ \sigma \kappa \omega$, covers the same semantic field as $\pi a\llcorner\delta \in \dot{\omega} \omega$ and derivatives in this Gospel.

This was not only the case in Jewish societies. Tacitus in his Dialogus de Oratoribus 28-29 emphasizes the thorough education which the parent should give his child. Syriac Menander (2.20) says that the child (son) should listen to the words of both his father and mother.

Neyrey (1996:120).

Dixon (1991:118).

This was also case elsewhere in social ecology - Tacitus Dialogus de Oratoribus 28-29; Syriac Menander 2.20.

33 This "character" as expressed in the customs and traditions of the family, was highly regarded as something to protect and desire. See Josephus Ant. 1.3.1 \$72. In 1 Macc. 1:54-58; 2:15-28; 4:36-43 Mattathias confirms his and his son's loyalty towards the ways of their fathers. Dixon (1991:111) says that Roman children inherited the "family name and honour and the obligations that go with them - the continuation of the family cult...the maintenance of the family traditions".

See Keil (1888:177). Christ (1984:10) claims: "For its children the duty of religiously sanctioned obligations towards the parents corresponded to that of the relations between men and gods".

Roberts (1984:157) puts it quite clearly: "The oikos and the father's position therein being the foundation of society...Any form of disrespect of parents was prohibited".

36 A switch in words from seed ( $\sigma \pi \dot{\rho} \rho \mu \alpha-8: 33,37)$ to children ( $\tau \dot{\varepsilon} \kappa v \alpha-8: 39)$ might indicate the change in status. Seed might indicate their position as those who stand in the tradition of Abraham, while children might refer to 
their present physical status. They have actually left the family and their traditions and cannot claim to be children of Abraham, since they do not do what he asks. If this line of argument is plausible, this might be a subtle remark on the position of the Jews within the conflict with the Johannine group.

That it is probable that the idea of tradition is implied in 8:34-47 may be argued from several points, for instance, this section deals with behaviour learned from their father as carrier of the tradition related to behaviour; the opponents' father, the devil was the origin of their tradition for murder and hate and they follow him now; Abraham lies far back in history and therefore represents a figure whose traditions should be followed.

This is evident from the question asked by the Jews in 7:15 that the knowledge of Jesus astounds (see also the remark of the officers in 7:46) them because they are not aware that he had studied with somebody (Пîs

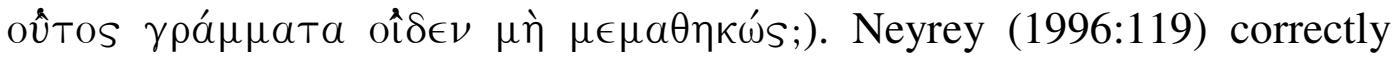
points out that the question was whether a wise and respected teacher taught Jesus. That would have determined his position of honour in the eyes of the community. He quotes Menander Rhetor (Treatise II.371.17-372.2) to support his argument. Learners bore the stamps of their mentors and teachers: "young men were only as good as their teachers and those who formed them in the social values enshrined in their past culture" (Neyrey 1996:120). It should also be noted that simultaneously teaching your child a vocation and giving him moral instruction, or even another form of higher learning, was contrary to the rest of the ancient societies, completely compatible in the Jewish society (Lemaire 1996:ad loc.; Cf. for instance Paul in Luke 18:3 or 1 Cor 4:12). The remark by the Jewish opponents is ironic. They do not know who taught Jesus, although Jesus' knowledge makes it apparent that he must have had an important teacher, whom they were supposed to know. Jesus identifies his teacher as the one who has sent him, namely God (7:16ff. - 8:55). The honour he therefore seeks is not his own, but that of his teacher, the Father. It seems that the education of Jesus by the Father includes not only vocational training but also specialized training in morals and further knowledge.

"How did this man get such learning without having studied?"

Neyrey (1996:119) points out that the question was whether a wise and respected teacher taught Jesus. That would have determined his position in the eyes of the community. He quotes Menander Rhetor (Treatise II.371.17372.2).

41 Neyrey (1996:120).

42 Modern children are encouraged to explore and discover for themselves and develop their own opinions. This is a far cry from what was expected from a child in the ancient Mediterranean world. 
Van Tilborg (1993:30) also points out that the Father is presented as an ideal Father. See Sir. 30:1-5.

Johnson (1995:196) mentions: "The transmission of wisdom from father to son is, of course, the standard mise-en-scène of parenesis". See Roberts (1984:63).

45

"From Homeric to historical times Greek society remained founded on the oikos or household, with the father's power therein almost unfettered. It was the business of the father to pass on the oikos to his son at least as strong as he had inherited it" (Roberts 1984:157). This implies a strong educational tradition.

It must be noted that the fact that a child acts as his father does was not only due to the education of that particular child by the father. It was due to that person's bloodline too. Pliny the Younger (Letters 8.10) emphasizes that his children will be good politicians because they will have a long line of famous political ancestors.

Education did not only have economic value, but also served as a way in which family tradition was protected and handed on from one generation to the next generation. In 1 Macc. 2:15-28 (see also 1:54-58 and 4:36-43) it is described how Mattathias and his sons are asked to obey the king. Mattathias answered that he would rather stick to his own traditions and stay loyal to the covenant of his ancestors. From that passage the corporate effect of his decision is clear. Plutarch (The Life of Marcus Cato 20.4-7) tells with great care how Cato gave his son "the opportunity at home to become familiar with his society's ancient customs and traditions" (Shelton 1988:105).

48 Barrett (1978:259).

49 Obviously it is not implied that everywhere in the ancient world people educated their children in this manner only. What is said here is that similar patterns of education are well-known in the ancient world. In any case, John himself gives the reader an indication of what he thinks takes place during the educational process of Jesus by the Father. 